KOŚCIÓŁ I PRAWO 9(22) 2020, nr 2, s. 37-48

DOI: http://dx.doi.org/10.18290/kip2092-3

\title{
Oleksandr Levytskyy
}

\section{CLERGY FORMATION IN THE PROVISIONS OF ZAMOŚĆ AND LVIV SYNODS}

\section{PROBLEM STATEMENT}

The complete and proper priesthood education had remained an unsolved problem for the Ruthenian Clergy. It is important to mention that at the beginning of the 18th century the quality of clerical education among the eparchial priesthood candidates was considerably low. The candidates who had received their tuition at home were extremely poorly prepared. Those candidates who aimed to study the basics of theological studies were forced to learn them in Latin schools, Basilian schools or in seminary schools at bishops' cathedrals.

The aim of this article is to explore the clergy formation within the decrees of the Synods of Zamość and Lviv.

\section{STATEMENT OF BASIC MATERIALS}

The first attempts of solving the clergy training and education problem were made at the Synod of Zamość in 1720. This topic was given great attention, but no cardinal changes were implemented. Nevertheless, understanding of the issue and readiness to work on improving in this sphere

Rev. OleksandR LevyTskyY, Ph.D. - Faculty of Theology, Ivano-Frankivsk Academy of John Chrysostom; e-mail: olevytsky@ukr.net; http://orcid.org/0000-0002-92353887 
were expressed, and a certain vision on solving the problem of education for all the clergy was developed. While the aforementioned thoughts had a positive direction, their practical implementation proved to be challenging.

Among the most important regulations of the Synod was an obligation to open theological schools at any monastery which inhabited more than 12 monks. The aim of this decision was not only to satisfy the needs of the monastery in question, but also to upbring priests for the diocese. In regards of clergy candidates, the resolution went as follows: "The Holy Synod encourages all of the bishops that cannot afford opening a theological seminary in their dioceses to send the most talented youth, especially the sons of pastors, to the Pontifical College in Lviv for receiving education and learning the basics of theological lore, studying the good traditions [...]" [Kozovyk 2006, 253].

In reality, there was only one higher education clergy school on the territory of Ukraine at the time - Pontifical Ruthenian-Armenian College in Lviv [Blazejovskyj 1975, 12]. Additionally, cathedral and monastery schools were functioning as well. Several bishops at the Synod of Zamość declared their intention to support financially a certain number of candidates within their dioceses. The degrees also concerned the seminary which had already been functioning at Volodymyr Cathedral thanks to Metropolitan Lev Kishka's initiative. However, the schools at the time could not be considered seminaries as we know them today. The requirements of the educational program were set by the Synod: "Priests and deans should see to it that the students receive a Christian upbringing, know the payers «Our Father», «Hail Mary», «Symbol of Faith», God's and the Church's commandments by heart, learn catechism and are able to read and write" [Kozovyk 2006, 255].

As for the demands for consecrations, they were written down in a different part of the statutes which was dedicated to the sacrament of priesthood. The bishops established that any clergy candidate should be thoroughly tested using the rules implemented by the Council of Trent. The stages and methods of preparation for entering the priesthood were thoroughly explained. The examination commission that approved clergy candidates was presided over by a specifically appointed diocesan theologian. Among other members of the commission there was an official, i.e. the Vicar General, and the examiners appointed by the bishop [ibid., 185]. 
Apart from the candidates' knowledge, the commission tested their ability to fulfill their priestly duties, specifically, their behavior, spiritual life, good habits, lack of obstacles for becoming a priest. The candidate's pastor was required to deliver several announcements in his church so that the believers were able to express their protests or objections if the candidate was inappropriate or unable to submit to a consecration. Later on, the candidate stayed in the parish for a certain period of time, established by a bishop or an official, taking part in worships and services. The candidate's pastor, after all of the checks had been finished and all of the key issues concerning the candidate's abilities had been resolved, sent a report to the bishop. After that, the candidate received a further training at the bishop's cathedral for six weeks and was also required to complete a 10-days recollections under the guidance of the recollectant, appointed by the bishop. It was only after all of the stages had been passed successfully that the candidate could face the examination commission that checked his professional knowledge, abilities and behaviour. Practical aspects of priesthood, like performing holy sacraments and fulfilling parochial duties, were tested at the exam as well, in the bishop's presence. The Synod prohibited to ordain the following categories of candidates: serfs, neophytes, bigamists, cripples, drunkards, epileptics, criminals, debtors, people punished by the Church and people of no good behaviour and reputation among the others [ibid., 183-91]. All of the prohibitions and canonical hindrances were derived directly from the decrees of the Council of Trent, which the bishops of the Synod of Zamość used as a model for implementing new rules and reformations in different areas of the Church's life. The Synod of Zamość became a turning point for the Ukrainian Church, adding more clarity to its development and activity.

Consequently, the clergy education situation changed in the second half of the 18th century, due to all of the efforts to practically apply the decrees of Synod of Zamość, which, in its turn, improved the quality of examinations for clergy candidates and raised the level of upbringing in most schools and colleges.

The foundation of seminaries equaled the parish clergy reformation, the latter being greatly needed for the spiritual life of Ruthenian commonwealth. In order to fulfill this reform, a change of priesthood mentality was necessary to happen, when the priests would abandon their desire of profit and strive towards raising the spiritual level of believers. The 
change of this nature couldn't come to a reality without continuous spiritual upbringing and theological teaching in seminaries.

If we consider the specific practices within the realm of clergy candidates training at the time we will find out that there was a tendency to follow the decrees of the Synod of Zamość, adopted by the bishops of Lviv. Particularly, in the constitutions of the Council of Lviv, 1738, the regulations of the synod were confirmed. The candidates had to gain basic lore at school, receive recommendations from their pastor and dean, submit them to the official or bishop, be free from any servitude and have a financial background to buy the priestly vestments. The sons of priests had a privilege over the commoners when it came to consecration [Skochylyas 2006, 290]. In the upcoming decades it was decided to follow the demands of the synod more thoroughly.

Overall, the practice of clergy education remained the same, however no full-fledged seminaries were established at the time. At the seminary school, which functioned at the Kamyanets-Podilsky cathedral in 1793, commoners studied alongside with the candidates for priesthood. The candidates could receive basic mundane education at regular schools, albeit the seminary itself provided more specialized theological lore. Attention was given not only to education itself, but also to spiritual formation. It was forbidden to leave the boundaries of the school without permission. Moreover, the behaviour of the seminarians was under control, they were taught to keep everything clean and tidy, had to listen to and sing the Liturgy on a daily basis and confess monthly [ibid., 359].

At the beginning of the 17th century Lev Kishka, the bishop of Volodymyr, founded the eparchial seminary for the education of six people of his diocese, prior to the synod of Zamośc, having appointed a separate financial foundation for this goal [Haluschynskyj and Velykyj 1956, 89]. However, there is little data left regarding this institution. Perhaps the seminary was in some way linked to the school, which had been founded prior to the aforementioned seminary by Ipatiy Potiy. The school itself was governed by the Basilians [Bieńkowski 1969, 977].

The seminary of Holm was founded by the local bishop Maximilian Rylo. The local clergy and bishop decided to build the seminary for 30 seminarians of their diocese on the Eparchial Council in 1759. Their plan was realized. The bishop entrusted it to the three eparchial priests at first, but changed his mind in 1769 , thus entrusting it to Basilians. 
Sylvester Rudnytsky, the bishop of Lutsk, founded an eparchial seminary at his cathedral in 1763 [Haluschynskyj and Velykyj 1956, 326]. It didn't have any dedicated funding, though 30,000 zlotys of clergy taxes were gathered for its running. In 1779, after the bishop's death and a fire in the seminary, it decayed and the new bishop had no interest in its restoring; the seminary's fund was appointed for another purpose [Bieńkowski 1969, 978]. Rudnytsky's letter makes it clear that he planned to build not only the aforementioned seminary, but also to found a "scholam diocesanan pro ordinis" in his residence in Rozhyshchy [Rzemieniuk 1991, 67].

At the same time there was a bishop school that functioned as a seminary at Peremyshl cathedral. Despite of all the efforts of Peremyshl bishops, the opening and functioning of a separate seminary failed there [ibid., 68]. Jason Smogozhevsky, the archbishop of Polotsk, for a long period of time tried to found his own diocesan seminary as well.

Smogozhevsky proposed to establish a seminary in every eparchy in his "Desiderata" which was composed for the future Synod of Brest planned for 1756. The document described the aspect of education of would-be priests and provided that the seminary might accept candidates who reached the age of 17 . The teachers were to be picked from the former students of pontifical colleges and provided with salaries [Haluschynskyj and Velykyj 1956, 26]. However, the archbishop failed to get the approval of the Russian government for its foundation.

In 1722 bishop Atanasi Sheptytsky in his documents, among other issues, mentioned the state of clergy education in Lviv eparchy. According to this historical source, after the Theatines refused to accept the Greek Catholic clergy candidates to the pontifical Ruthenian-Armenian College in Lviv, he had to ordain the candidates who had finished ordinary schools [Skochylyas 2006, 364]. Therefore, during that period, the Uniate Church did not reach a correspondent level of education and training of its priesthood.

If we were to discuss the private seminaries, then it would be important to mention that such institutions were founded by the noblemen for the needs of parishes functioning within their domains. For example, in 1739, the building of the Basilian monastery in Sverzhan (Belarus) was funded by Prince Karol Stanislaw Radziwill, and a private five-year seminary was founded at that monastery in 1743 , where twelve sons of the 
Uniate priests from Radziwill's dominion could receive education [Sosnovskiy 1874,34$]$.

Several new schools were opened in the first half and in the middle of the 18th century, particularly, the St. Mykolay Church School in Bobruysk and the school of a higher grade in Zhyrovychy. In 1753, the Congregation of Deans in Novogrudok decreed to create three-year schools in every deanery in order to teach the children of priests to read liturgical books, to chant and to learn the order of a divine service. Eighteen schools of this type were planned to be opened: in Skidel, Ross, Orel, Mala Berestovytsia, Molodechno and some other towns [ibid., 37]. Priests refusing to send their children to study there were to be fined.

Empress Maria-Teresia, in order to satisfy the needs of her Galician subjects, established a special educational institution in Vienna in 1775 the Barbareum. According to Joseph Slipy, this became a starting point in solving the problem of a higher educational institution for the Ukrainian Church. The institution was supposed to provide education to clergy candidates from all of the Uniate dioceses within Austro-Hungary. Fourteen places were reserved for the candidates from Galicia. Bishop Vasyl Bozhykovych from Croatia supervised the seminary. The statute for the institution was created in 1780 on a basis of the rules operating in the Greek Collegium in Rome. After nearly 10 years of functioning, the seminary was closed by the next Emperor who changed the overall approach to clergy education by implanting the rule of creating general seminaries in every catholic diocese, regardless of its rite. Eparchial seminaries in the 18th century had short time curriculum, the quality of education varied depending on the seminary and they couldn't satisfy the needs of the wide array of candidates to the priesthood.

The General Greek Catholic Theological Seminary was founded on the 30th of June, 1783 in Lviv [Androkhovych 1936, 61] for the major number of Greek Catholic clergy of Galicia. The tuition in that seminary complimented the mandatory education on the Theological Faculty of Lviv University. The creation of such an educational institution had a very positive effect, creating a new, truly educated generation of clergy.

The General Greek Catholic Theological Seminary was presided by the bishop as a rector while the prefect ran its internal affairs. Priests with an appropriate level of education were the tutors, sometimes they even had scientific degrees received abroad or in pontifical colleges in Rzech Po- 
spolita. Most of the subjects were taught in the Old Ukrainian language, while the others, such as pastoral theology, were taught in Polish at Lviv University. The seminary's subjects included moral and dogmatic theology, Latin, homiletics, catechism, logic, metaphysics. Regarding pastoral practice, special attention and a lot of time were devoted to the lore, habits and skills required to administer the holy sacraments; the seminarians were also taught the duties of the pastor and moral casuistry. They had a lot of practice sessions where they exercised preaching. The seminarians were also taught church singing after Kyivan irmologion, studied the customs and the church charter of Liturgy. Exceptional attention was paid to behavioral skills and etiquette. After the completion of the studies, which lasted for four years, the candidates to priesthood had to take an exam before a special commission, which consisted of four professors and a bishop. The exams in moral and pastoral theology were taken at the university.

Later, in 1848-1914 not only the theologians of Lviv archdiocese, but of Peremyshl and Stanislaw eparchies as well, could become the students of the General Greek Catholic Theological Seminary in Lviv. The most talented of them continued their study and gained scientific degrees in various prestige educational institutions of Europe. The candidates to priesthood who had completed their studies in Latin colleges or schools were obliged to receive supplementary lore during three months at the General or eparchial seminary. This applied primarily to the aspects of studying the customs and Liturgies, etc. [Idem 1921, 135].

At the end of 18th and the beginning of 19th centuries there were five operating seminaries of the UGCC. These were the eparchial seminaries of Lviv, Halych, Kamyanets-Podilsky, Bar and Peremyshl. The staff number as well as the curriculum were somewhat reduced, both in subjects and a period of study (one or two years); however later the latter was increased up to four years.

The Belarus Seminary in Polotsk which became an authoritative educational institution for the entirety of the UGCC was opened in 1806. By the year of 1825, thirteen of its students earned a Doctorate. The Brest Seminary started its activity in Lavryshev. The ones who taught there were highly educated and experienced professors coming from the Belarusian nobility as a rule [Marozava 1997, 3-4]. In 1803 the Main Seminary was founded at the university of Vilnius - the first and the only Uniate institution of higher education, in which the most talented youth, who had 
completed the study at eparchial seminaries, was trained for higher church positions. However, the university was closed by the royal decree in 1832; the Russian imperial government didn't want to have an educated Uniate clergy.

In the middle of the 19th century $71.4 \%$ of seminaries graduates were the sons of priests, which showed the traditional replenishment of clergy, while the other $28.57 \%$ of graduates came from other social stratums (townsfolk, villagers, employees, teachers).

Throughout almost the entire 19th century there existed a great need for some quality changes within the intellectual and spiritual formation of diocese clergy. Joseph and Sylvester Sembratovyches, the Metropolitans of Halych, tried to draw attention to the situation with the educational system in seminaries.

The Lviv Provincial Synod in 1891 started the reorganization of the seminary system of the Greek Catholic Church, which aimed at improving the role of eparchial seminaries and reinforcing the direct influence of the bishop on clergy candidates. Firstly, the bishops divided the seminaries into two types: minor seminary and major seminary. People who didn't have a clear intention of becoming priests studied at the seminaries of the first type. The second type prepared candidates for the priesthood. There was only one seminary of that type for the whole Metropolis. The seminary was to function according to the regulations of the Council of Trent. Great attention was paid to the tutors, who had to set a good example for the seminarians.

The biggest emphasis was put on the clergy formation itself. Rules were set regarding candidates' behaviour inside and outside the seminary, particularly during a vacation period. A priesthood candidate had to submit a reference written by his pastor to the rector after returning from holidays. While at home, a seminarian had to show exemplary behaviour in his relations with different people, help his pastor in the cathedral during divine services and at teaching the catechism. While studying at the seminary, a candidate had to confess and receive the Eucharist once or twice a month, ponder the holy scripts for at least half an hour every day, test his conscience, be present at the Liturgy, take part in the spiritual exercises, especially recollections. Every seminary student had to be particularly faithful to the Holy Mother. 
Relatively less attention was paid to the aspects of education itself. The regulations set the demands for the tutors and outlined the main directions in studying the theological subjects. The most attention was given to the following subjects: studying the Bible, homiletics, the Church-Slavonic language, practice of the divine services and rituals. ${ }^{1}$

Considering the clergy consecrations, the Synod of Lviv confirmed the regulations of the Synod of Zamość: subdeacons were ordained at the age of 21 , deacons - at the age of 22 and priests - at the age of 24 . Before any of those consecrations could take place, a candidate had to go through the eight-day recollections and the confession. ${ }^{2}$

Following the decrees of the Synod of Lviv, the General Seminary in Lviv was closed down in 1893 in order to found a separate eparchial seminary in every diocese. Thus, three new seminaries were formed in the 19th century: in Lviv, Stanislaw and Peremyshl. However, while the seminaries in other eparchies were being created, there was a period of time when only the Lviv Seminary functioned normally, meaning it educated the clergy candidates from not only the Lviv region, but also from the regions of Stanislaw and Peremyshl. 89 seminarians were being trained at the time, with 10 others studying at the Ukrainian College in Rome [Korolevsky 1993, 84].

Continuing the reforms, the document called "Pravyla dla Seminariyi bolshoi and menshoi" ("Regulations for the Seminary minor and major") was released in 1897 and published in the appendix to the decrees and decisions of the Synod of Lviv [Hrenyak 1897, 443-68]. The document in question had a form of general statute regulations for the activity of seminaries. According to the regulations, the seminarians were obliged to obey the rector in every aspect as far as their spiritual upbringing, studying and discipline were concerned; to live together in unity and love, not standing out with different provision or clothing; to be modest in their nourishment, diligent in their studies, clean and tidy in their everyday life; to keep quiet in the seminary. The seminarians were forbidden from entering staff rooms and the rooms of the priors (except for the rooms of the rector and their confessor). The seminarians' contacts outside the premises of the institution were under the control of the priors (usually

\footnotetext{
${ }^{1}$ Chynnosty y rishenya Ruskoho Provyntsiyal'noho Sobora v Halychyni otbuvshaho sya vo L'vovi v rotsi 1891, L'vov 1896, p. 213-18.

${ }^{2}$ Ibid., p. 101-102.
} 
the rector); leisure-time activities, duties and the daily schedule were regulated as well.

\section{CONCLUSIONS}

To sum it up, in the first half of the 18th century and at the end of the 19 th century serious attempts to solve the actual problems of the education and formation of new professionals for the Church were made by the higher Church authorities and some representatives of the secular power. It can be stated that the Synod of Zamość in particular had laid the foundation for the successive clergy training by establishing general norms for all of the dioceses. The regulations of the Synod touched on the pressing issues and made a great contribution to the process of the foundation of new educational institutions for the preparation of priests for the Kievan Church. Thus, the spiritual life of the United Kyivan Metropolis received a new momentum after the Synod of Zamość which allowed it to enter its "Golden Age" in the 18th century.

In 1891, the Synod of Lviv took place, where the laity participated as well, and the issue of providing eparchies with well-educated priests was conceptually resolved. The Synod of Lviv in 1891 had also developed a number of important and determinant resolutions which influenced the religious processes in the context of founding seminaries and preparing highly educated, well-bred and accomplished priests.

A new model of theological education had a great impact on developing quite a novel approach to clergy formation. The reforms had an enormous positive influence on the professional theological and moral state of the Greek Catholic clergy.

\section{REFERENCES}

Androkhovych, Amvroziy. 1921. "L'vivs'ke «Studium Ruthenum»." Zapysky Naukovoho tovarystva imeny Shevchenka 131:123-95.

Androkhovych, Amvroziy. 1936. "Istoriya hreko-katolyts'koyi General'noyi Dukhovnoyi Semynariyi u L'vovi 1783-1810.” In Pratsi hreko-katolyts'koyi Bohoslovs'koyi Akademiyi u L'vovi. Hreko-katolyts'ka dukhovna semynariya u L'vovi. Materiyaly i rozvidky zibrav o. prof. dr Yosyf Slipyy.1936, vol. 3, 61-505. L'viv: Bibl'os. 
Bieńkowski, Ludomir. 1969. "Organizacja Kościoła Wschodniego w Polsce.” In Kościót $w$ Polsce (Studia nad Historia Kościoła Katolickiego $w$ Polsce). Vol. 2: Wieki XVIXVIII, ed. Jerzy Kłoczowski, 781-1049. Kraków: Znak.

Blazejovskyj, Dmytro. 1975. Ukrainian and Armenian Pontifical Seminaries of Lviv (1665-1784). Rome: P. P. Basiliani.

Haluschynskyj, Teodosij, and Atanasij Velykyj, ed. 1956-1964. Epistolae metropolitarum, archiepiscoporum et episcoporum. Vol. Haluschynskyj 1-9. Romae: P. P. Basiliani.

Hrenyak, Yoakym. 1897. Dodatok do chynnostey y rishen' Ruskoho Provyntsiyal'noho Sobora $v$ Halychyni otbuvshoho sya vo L'vovi v rotsi 1891. L'vov: Drukarnia Stavropihiyskoho Ynstytuta.

Korolevsky, Cyril. 1993. Metropolitan Andrew (1865-1944). Translated and Revised by Serge Keleher. Lviv: Stauropegion.

Kozovyk, Ivan. 2006. Provintsiynyy Synod u Zamosti 1720 roku Bozhoho. Postanovy. Ivano-Frankivs'k: Nova Zorya.

Marozava, Svjatlana. 1997. "Pieršy adukacyjny zachad unijackaj carkvy. Nacyjanaĺnaja adukacyja." In Kniha VIII: Nacyjanaĺnaja adukacyja bielaruska-pol'skalitouskaha sumezhzha, ed. Sierhiej Jackievič, 3-18. Brest: Mizhnar. Akademija vyvuch. natsyjan. menshastsej.

Rzemieniuk, Florentyna. 1991. Unickie szkoty początkowe w Królestwie Polskim i w Galicji 1772-1914. Lublin: Towarzystwo Naukowe KUL.

Skochylyas, Ihor. 2006. Sobory L'vivs'koyi yeparkhiyi XVI-XVIII stolit'. L'viv: Vydavnytstvo Ukrayins'koho Katolyts'koho Universytetu.

Sosnovskiy, Anton. 1874. "O sryedstvakh umnozheniya v hryeko-uniatskom dukhovyenstvye prosvyeshchyeniya.” Litovskiye yeparkhial'nyye vyedomosti 20-21:32-46.

\section{Clergy Formation in the Provisions of Zamość and Lviv Synods}

\section{Summary}

The paper analyses the stages of formation of the clergy in the provisions of the synods of Zamość and Lviv. The research aims to clarify and structure the main approaches and principles of the clergy formation process in the statutes of the $1720 \mathrm{Za}$ mość Synod of and the 1891 Lviv Synod. Particularly, the author analysed the normative documents of these synods concerning the regulation of the formation of the clergy in the Church. The stages and methods for preparing candidates for the priesthood are considered. The emphasis is on a gradual logical ordering of the normative documents concerning priestly formation in the Ukrainian Church.

Key words: clergy; Zamość synod; Lviv synod; seminary; formation 


\title{
Formacja duchowieństwa \\ w postanowieniach Synodów Zamojskiego i Lwowskiego
}

\begin{abstract}
Streszczenie
Artykuł analizuje etapy formacji duchowieństwa w postanowieniach Synodów Zamojskiego i Lwowskiego. Badania mają na celu wyjaśnienie i ustrukturyzowanie głównych podejść i zasad procesu formacji duchowieństwa w postanowieniach Synodu Zamojskiego z 1720 r. i Synodu Lwowskiego z 1891 r. W szczególności autor przeanalizował dokumenty normatywne tych synodów, które dotyczą regulacji formacji duchowieństwa w Kościele. Rozważane są etapy i metody przygotowania kandydatów do kapłaństwa. Nacisk kładzie się na stopniowe logiczne uporządkowanie dokumentów normatywnych dotyczących formacji kapłańskiej w Kościele ukraińskim.
\end{abstract}

Słowa kluczowe: duchowieństwo; Synod Zamojski; Synod Lwowski; seminarium duchowne; formacja

Informacje o Autorze: Ks. DR OLEKSANDR LEVYTSKYY - Wydział Teologii, Iwano-Frankowska Akademia Jana Chryzostoma; e-mail: olevytsky@ukr.net; http://orcid. org/0000-0002-9235-3887 